ISSN 1678-3921

Journal homepage: www.embrapa.br/pab

For manuscript submission and journal contents, access: www.scielo.br/pab

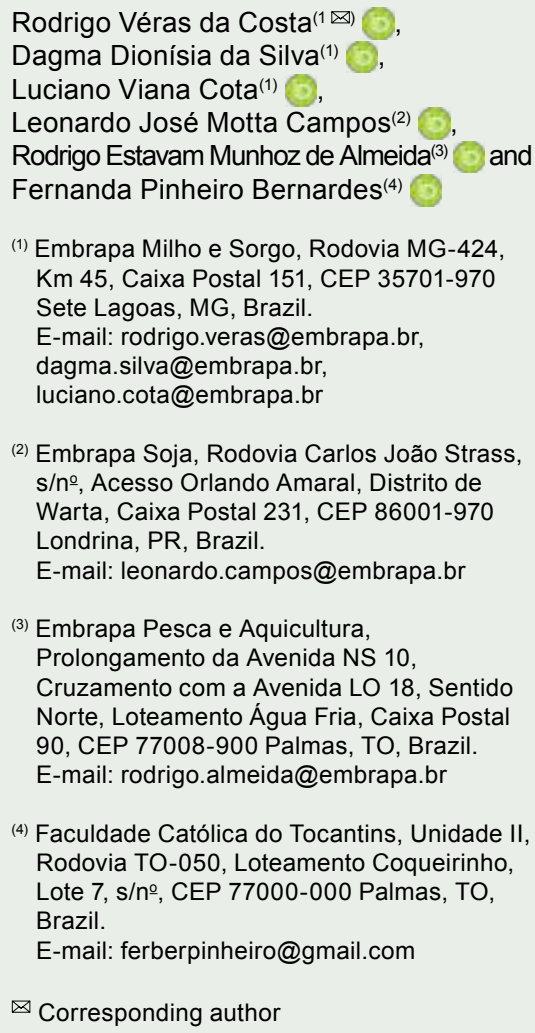

\section{Incidence of corn stunt disease in off-season corn hybrids in different sowing seasons}

\begin{abstract}
The objective of this work was to evaluate the incidence of corn stunt disease and its effects on the grain yield of off-season corn (Zea mays) hybrids in different sowing seasons. The experiment was conducted in three sites in the state of Tocantins, in different sowing seasons, in a randomized complete block design, with 30 hybrids (treatments) and three replicates. Corn stunt disease incidence was assessed at 80 days after emergence, varying between hybrids and sowing seasons, with a marked effect of sowing season. The most resistant hybrids were: MG652 PW, Penta VIP, MG600 PW, NS90 PRO2, LG3040 VIP3, MG580 PW, and Defender VIP. The Fórmula VIP2 hybrid was the most susceptible to corn stunt disease. The incidence of the disease increased in the later sowing seasons, causing significant declines in grain yield. The most productive hybrids were: MG580 PW, SYN 5T78 VIP, 2B810 PRO, MG600 PW, Supremo VIP, 2B512 PW, NS92 PRO2, P30S31 VYH, MG652 PW, Penta VIP, SX5371 VIP3, and LG6036 PRO. Corn hybrids vary greatly in their resistance to corn stunt disease, and, the later the sowing season, the higher the disease incidence and the lower the grain yield.
\end{abstract}

Index terms: Dalbulus maidis, Zea mays, genetic resistance, Mollicutes, phytoplasma, spiroplasma.

\section{Incidência de enfezamentos em híbridos de milho safrinha em diferentes épocas de semeadura}

Resumo - O objetivo deste trabalho foi avaliar a incidência de enfezamentos e os seus efeitos na produtividade de híbridos de milho (Zea mays) safrinha em diferentes épocas de semeadura. O experimento foi conduzido em três locais no Estado do Tocantins, em épocas de semeadura distintas, em delineamento experimental de blocos ao acaso, com 30 híbridos (tratamentos) e três repetições. A incidência de enfezamentos foi avaliada aos 80 dias após emergência, tendo variado entre híbridos e épocas de semeadura, com efeito pronunciado da época de semeadura. Os híbridos mais resistentes foram: MG652 PW, Penta VIP, MG600 PW, NS90 PRO2, LG3040 VIP3, MG580 PW e Defender VIP. O híbrido Fórmula VIP2 foi o mais suscetível aos enfezamentos. A incidência da doença aumentou nas épocas de semeadura mais tardias, com redução significativa da produtividade de grãos. Os híbridos mais produtivos foram: MG580 PW, SYN 5T78 VIP, 2B810 PRO, MG600 PW, Supremo VIP, 2B512 PW, NS92 PRO2, P30S31 VYH, MG652 PW, Penta VIP, SX5371 VIP3 e LG6036 PRO. Os híbridos de milho variam muito na sua resistência aos enfezamentos, e, quanto mais tardia a semeadura, maior a incidência da doença e menor a produtividade de grãos.

Termos para indexação: Dalbulus maidis, Zea mays, resistência genética, Mollicutes, fitoplasma, espiroplasma. 


\section{Introduction}

Corn (Zea mays L.) stunt diseases, such as maize bushy stunt and corn stunt spiroplasma, are systemic diseases caused by bacteria of the Mollicutes class. These bacteria infect corn phloem tissues and are persistently propagated by the corn leafhopper Dalbulus maidis DeLong \& Wolcott, Homoptera: Cicadellidae (Nault, 1980; Whitcomb et al., 1986).

Due to their historical low incidence, stunt diseases have long been considered less harmful than other ones. However, changes in the corn farming system, particularly the introduction of biotechnology, and the increased use of off-season corn (sown between February and March), have increased the incidence of corn stunt disease, causing significant production losses. Currently, corn stunt diseases are considered one of the main phytosanitary problems of off-season corn (Silveira et al, 2008).

In Brazil, for example, in the summer of 2016/2017, with sowing from October to November, several cases of epidemic outbreaks of corn stunt disease were reported for off-season corn in the states of Goiás, Mato Grosso, Minas Gerais, and Bahia, accompanied by sharp losses in productivity. According to Teixeira et al. (2013) and Oliveira et al. (2007), these losses vary as a function of sowing time and hybrid susceptibility.

For corn stunt disease management, the following measures are recommended: avoiding sowing corn near diseased crops, synchronizing planting seasons, eliminating corn stover, using resistant hybrids, performing seed treatments, and chemically or biologically controlling the insect vector (Marquardt et al., 2013; Silva et al., 2017).

However, given the low efficiency of the chemical control of the vector and of the other isolated measures, the use of resistant hybrids is the main alternative to reduce the incidence of and damage caused by corn stunt disease (Oliveira \& Sabato, 2017; Silva et al., 2017). It should be noted that the term "resistance" refers to the specific ability of a plant to restrict infection or the further development of the pathogen in its tissues, which should show minimal or no disease symptoms.

Few studies, however, have sought to identify genetic control and sources of resistance to corn stunt disease in improvement programs (Moro et al., 2007; Teixeira et al., 2013), probably due to the fact that the epidemic outbreaks of corn stunt disease have only occurred recently. Therefore, there is still a lack of information on the resistance of modern commercial hybrids available in the market and also on their behavior in the field, where they are subjected to interactions between biotic and abiotic factors.

Sowing season also plays a key role in disease development and dissemination, since, in the field, infectious leafhoppers migrate from older, diseased crops to younger ones (Oliveira et al., 2013), infecting healthy seedlings early in the crop development cycle. This shows the need to study the reaction of off-season corn hybrids to different sowing seasons.

The objective of this work was to evaluate the incidence of corn stunt disease and its effects on the grain yield of off-season corn hybrids in different sowing seasons.

\section{Materials and Methods}

Three field experiments were conducted under rainfed conditions in the state of Tocantins, Brazil, in grain (summer soybean and off-season corn) farms, in the municipalities of Pedro Afonso $\left(9^{\circ} 10^{\prime} 16^{\prime \prime S}\right.$, $48^{\circ} 15^{\prime} 23^{\prime \prime} \mathrm{W}$, at $245 \mathrm{~m}$ above sea level), Aparecida do Rio Negro $\left(10^{\circ} 01^{\prime} 21^{\prime \prime} \mathrm{S}, 48^{\circ} 15^{\prime} 12^{\prime \prime} \mathrm{W}\right.$, at $550 \mathrm{~m}$ above sea level), and Porto Nacional (1047'06"S, 48 $31^{\circ} 42^{\prime \prime} \mathrm{W}$, at $277 \mathrm{~m}$ above sea level). In all study areas, the soil was classified as a Latossolo Vermelho Amarelo distrófico (Santos et al., 2013), i.e., a Typic Haplustox, and the climate, as Aw, tropical savanna with dry winters, according to Köppen's classification. Data on monthly precipitation and total precipitation volume for each site, from January to June 2017, are shown in Figure 1.

The experiment was conducted in a randomized complete block design, with 30 corn hybrids (treatments) and three replicates in each site. The experimental plots consisted of four 5.0-m rows, with $0.5-\mathrm{m}$ spacing between them and an average plant density of 65,000 plants per hectare. The following hybrids were used: Fórmula VIP2, considered as the standard for corn stunt disease susceptibility; LG6036 PRO, NS70, P2830 VYH, 2B512 PW, Supremo VIP, P30S31 VYH, LG6033 PRO, MG652 PW, Penta VIP, MG600 PW, NS90 PRO2, LG3040 VIP3, MG580 PW, Defender VIP, P3456 VYH, LG3055 PRO, BM3063 PRO2, NS92 PRO2, DKB310 PRO3, P30F35, Truck VIP, DKB290 PRO3, 2B810 PRO, DKB390 PRO3, 2B655 PW, LG6304 PRO, and RIBER 9110 PRO, 
commercial hybrids; and SYN5T78 VIP and SX7341 VIP3, hybrids in the pre-launch phase.

The hybrids were sown in Pedro Afonso on $2 / 15 / 2017$, in Porto Nacional on $2 / 24 / 2017$, and in Aparecida do Rio Negro on 3/14/2017. Fertilization consisted of side-dressing with $130 \mathrm{~kg} \mathrm{ha}^{-1} \mathrm{P}_{2} \mathrm{O}_{5}$ and $27 \mathrm{~kg} \mathrm{ha}^{-1}$ nitrogen, and of topdressing with $90 \mathrm{~kg} \mathrm{ha}^{-1}$ nitrogen, in the form of urea, in the four-to-six leaf phase. Seeds were treated with $0.08 \mathrm{~L}$ thiamethoxam per 60,000 seeds. Other plant pest control measures, such as pest and leaf disease control and weeding, were performed according to the standard operating procedures of the farms.

Corn stunt disease incidence was assessed 80 days after emergence. Disease incidence was calculated as the ratio between the number of plants with stunt symptoms (red stripes on leaves, white streaks, reduced plant height, sprouts, and ear proliferation) and the total number of plants in the two central rows of each plot. Data were expressed as percentage (\%) of diseased plants. Because it is difficult to differentiate between symptoms of both types of corn stunt disease (maize bushy stunt and corn stunt spiroplasma) in the field and because both diseases may occur on the same plant, "stunt disease" was used as a general term for both diseases in the present study. The hybrids that showed a significantly lower incidence of diseased plants compared with the other ones were considered to be more resistant, and vice versa.

At the end of the crop cycle, ears were harvested from the two central rows of each plot. The ears were counted, shelled, and weighed on digital scales $(10 \mathrm{~kg} \times 0.1 \mathrm{~g}$ accuracy), and the moisture content of each ear was determined using the Mini GAC Plus (Agrosystem, Ribeirão Preto, SP, Brazil) handheld moisture tester, accurate to $0.1 \%$ moisture. Grain

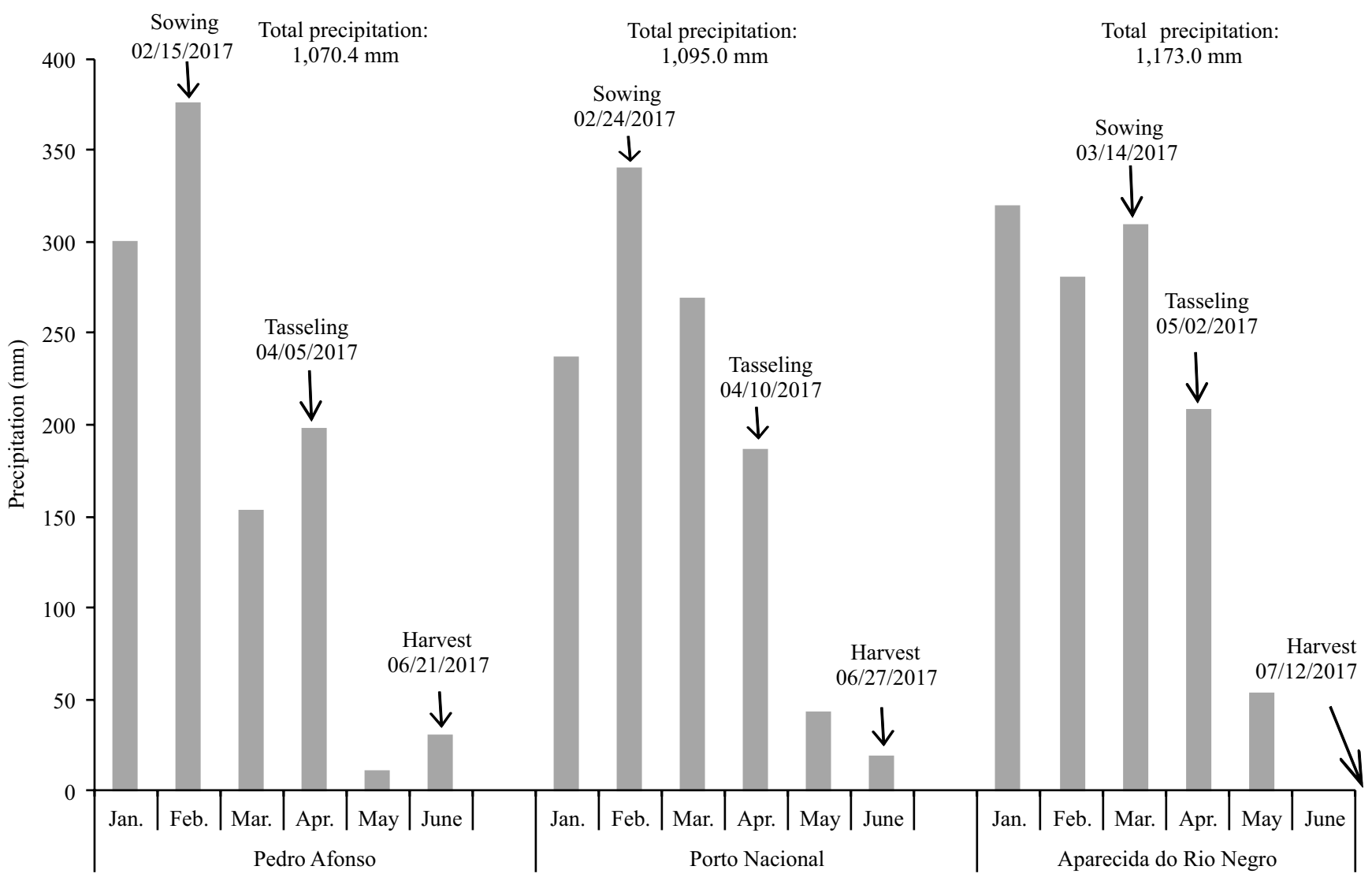

Figure 1. Monthly precipitation in the Pedro Afonso, Porto Nacional, and Aparecida do Rio Negro experimental sites (municipalities), in the state of Tocantins, in the 2017 off-season. 
weight was adjusted to $13 \%$ moisture, and grain yield was expressed in $\mathrm{kg} \mathrm{ha}^{-1}$. The average grain weight per ear (AGWE), expressed in grams, was calculated by dividing the total grain weight for each plot by the total number of ears.

Corn stunt disease incidence, grain yield, and AGWE data were subjected to individual and combined analyses of variance. Means, when necessary, were compared by the Scott-Knott test, at 5\% probability. In addition, Pearson's correlation coefficient was calculated using the means of the three studied variables.

\section{Results and Discussion}

There was a significant interaction between sowing season and corn hybrids regarding corn stunt disease incidence, grain yield, and AGWE, which is an indicative that the isolated effects of the studied factors do not account for all variation found in these characteristics (Table 1).

The incidence of corn stunt disease in the hybrids increased the later the sowing season (Table 2). In the first planting, performed in Pedro Afonso on 2/15/2017, only the Fórmula VIP2 hybrid, considered the susceptibility standard, showed the most severe disease symptoms, with a mean incidence of $25.5 \%$; in this site, the mean disease incidence was $2.3 \%$. In the second planting, in Porto Nacional on 2/24/2017, the mean disease incidence was $24.2 \%$, higher than that in Pedro Afonso, and several hybrids showed

Table 1. Analysis of variance of corn stunt disease incidence, yield, and average grain weight per ear (AGWE) of corn (Zea mays) hybrids in experiments conducted in the municipalities of Pedro Afonso, Aparecida do Rio Negro, and Porto Nacional, in the state of Tocantins, Brazil, in the off-season of 2017.

\begin{tabular}{lcccc}
\hline Source & $\mathrm{DF}^{(1)}$ & \multicolumn{3}{c}{ Mean square } \\
\cline { 3 - 5 } & \multicolumn{5}{c}{$\begin{array}{c}\text { Corn stunt } \\
\text { disease }\end{array}$} & Yield & AGWE \\
\hline Sowing season (SS) & 2 & $24,672.2^{*}$ & $86,563,812.4^{*}$ & $9,574.3^{*}$ \\
Hybrids & 29 & $1,856.5^{*}$ & $2,287,121.3^{*}$ & $841.3^{*}$ \\
SS x hybrids & 58 & $511.6^{*}$ & $710,903.6^{*}$ & $256.4^{*}$ \\
Error & 89 & 36.4 & $640,259.2$ & 153.6 \\
\hline CV (\%) & & 14.8 & 11.4 & 10.9 \\
\hline
\end{tabular}

${ }^{(1)}$ Degrees of freedom. *Significant by the F-test, at $5 \%$ probability. high levels of disease incidence. In Aparecida do Rio Negro, where planting was carried out on 3/14/2017, disease incidence was also quite high, but few hybrids showed no severe disease symptoms; in this site, the mean disease incidence disease was $42 \%$.

Table 2. Corn stunt disease incidence (\%) in corn (Zea mays) hybrids in experiments conducted in the municipalities of Pedro Afonso (PA - sowing 02/15/2017), Porto Nacional (PN - sowing 02/14/2017), and Aparecida do Rio Negro (ARN sowing 03/14/2017), in the state of Tocantins, Brazil, in the off-season of $2017^{(1)}$.

\begin{tabular}{lcccc}
\hline Hybrids & PA & PN & ARN & Means \\
\hline MG652 PW & $1.0 \mathrm{Aa}$ & $2.5 \mathrm{Aa}$ & $2.5 \mathrm{Aa}$ & $2.0 \mathrm{~A}$ \\
Penta VIP & $1.2 \mathrm{Aa}$ & $2.5 \mathrm{Aa}$ & $4.3 \mathrm{Aa}$ & $2.3 \mathrm{~A}$ \\
MG600 PW & $1.0 \mathrm{Aa}$ & $2.5 \mathrm{Aa}$ & $6.0 \mathrm{Aa}$ & $3.2 \mathrm{~A}$ \\
NS90 PRO2 & $1.2 \mathrm{Aa}$ & $5.3 \mathrm{Aa}$ & $5.3 \mathrm{Aa}$ & $3.9 \mathrm{~A}$ \\
LG3040 VIP3 & $1.2 \mathrm{Aa}$ & $4.3 \mathrm{Aa}$ & $8.5 \mathrm{Aa}$ & $4.7 \mathrm{~A}$ \\
MG580 PW & $1.3 \mathrm{Aa}$ & $4.3 \mathrm{Aa}$ & $8.5 \mathrm{Aa}$ & $4.7 \mathrm{~A}$ \\
Defender VIP & $1.0 \mathrm{Aa}$ & $5.3 \mathrm{Aa}$ & $9.5 \mathrm{Aa}$ & $5.3 \mathrm{~A}$ \\
P3456 VYH & $1.3 \mathrm{Aa}$ & $8.5 \mathrm{Aa}$ & $13.0 \mathrm{Aa}$ & $7.6 \mathrm{~B}$ \\
SYN 5T78 VIP & $1.2 \mathrm{Aa}$ & $7.0 \mathrm{Aa}$ & $18.0 \mathrm{Bb}$ & $8.7 \mathrm{~B}$ \\
LG6036 PRO & $1.3 \mathrm{Aa}$ & $4.3 \mathrm{Aa}$ & $22.5 \mathrm{Bb}$ & $9.4 \mathrm{~B}$ \\
NS70 & $1.0 \mathrm{Aa}$ & $5.3 \mathrm{Aa}$ & $22.5 \mathrm{Bb}$ & $9.6 \mathrm{~B}$ \\
P2830 VYH & $1.0 \mathrm{Aa}$ & $8.5 \mathrm{Aa}$ & $21.0 \mathrm{Bb}$ & $10.2 \mathrm{~B}$ \\
2B512 PW & $1.0 \mathrm{Aa}$ & $3.0 \mathrm{Aa}$ & $28.0 \mathrm{Cb}$ & $10.7 \mathrm{~B}$ \\
Supremo VIP & $1.3 \mathrm{Aa}$ & $8.5 \mathrm{Aa}$ & $35.5 \mathrm{Cb}$ & $15.1 \mathrm{C}$ \\
LG3055 PRO & $1.2 \mathrm{Aa}$ & $15.0 \mathrm{Bb}$ & $35.5 \mathrm{Cb}$ & $17.2 \mathrm{C}$ \\
P30S31 VYH & $1.2 \mathrm{Aa}$ & $7.0 \mathrm{Aa}$ & $53.0 \mathrm{Db}$ & $20.4 \mathrm{C}$ \\
LG6033 PRO & $1.0 \mathrm{Aa}$ & $6.0 \mathrm{Aa}$ & $76.0 \mathrm{Fb}$ & $27.7 \mathrm{D}$ \\
SX7341 VIP3 & $1.0 \mathrm{Aa}$ & $31.0 \mathrm{Bb}$ & $57.5 \mathrm{Dc}$ & $29.8 \mathrm{D}$ \\
BM3063 PRO2 & $1.2 \mathrm{Aa}$ & $20.5 \mathrm{Bb}$ & $68.0 \mathrm{Ec}$ & $29.9 \mathrm{D}$ \\
NS92 PRO2 & $3.5 \mathrm{Aa}$ & $22.5 \mathrm{Bb}$ & $65.0 \mathrm{Ec}$ & $30.3 \mathrm{D}$ \\
DKB310 PRO3 & $1.3 \mathrm{Aa}$ & $25.5 \mathrm{Bb}$ & $70.0 \mathrm{Ec}$ & $32.3 \mathrm{D}$ \\
P30F35 & $7.0 \mathrm{Aa}$ & $40.0 \mathrm{Cb}$ & $55.5 \mathrm{Dc}$ & $34.2 \mathrm{D}$ \\
Truck VIP & $1.3 \mathrm{Aa}$ & $45.5 \mathrm{Cb}$ & $66.0 \mathrm{Ec}$ & $37.6 \mathrm{E}$ \\
DKB290 PRO3 & $1.2 \mathrm{Aa}$ & $53.0 \mathrm{Db}$ & $65.0 \mathrm{~Eb}$ & $39.7 \mathrm{E}$ \\
2B810 PRO & $1.3 \mathrm{Aa}$ & $55.5 \mathrm{Db}$ & $66.0 \mathrm{~Eb}$ & $40.9 \mathrm{E}$ \\
DKB390 PRO3 & $1.0 \mathrm{Aa}$ & $61.0 \mathrm{~Eb}$ & $63.0 \mathrm{~Eb}$ & $41.7 \mathrm{E}$ \\
2B655 PW & $4.0 \mathrm{Aa}$ & $55.0 \mathrm{Db}$ & $70.0 \mathrm{Ec}$ & $43.0 \mathrm{E}$ \\
LG6304 PRO & $1.0 \mathrm{Aa}$ & $66.0 \mathrm{~Eb}$ & $68.0 \mathrm{~Eb}$ & $45.0 \mathrm{E}$ \\
RIBER 9110 PRO & $70.0 \mathrm{~Eb}$ & $83.0 \mathrm{Fc}$ & $51.3 \mathrm{~F}$ \\
\hline Means & $79.5 \mathrm{Fb}$ & $92.5 \mathrm{Gc}$ & $65.8 \mathrm{G}$ \\
\hline the rows, do not differ by & the Scott-Knott test, at $5 \% \mathrm{probability.}$ \\
& & & &
\end{tabular}

Pesq. agropec. bras., Brasília, v.54, e00872, 2019

DOI: 10.1590/S1678-3921.pab2019.v54.00872 
Therefore, the incidence of corn stunt disease increased with the delay in sowing (Figure 2), as also observed by Oliveira et al. (2003). This may be explained by the fact that corn leafhoppers, which acquire Mollicutes by ingesting the infected sap of diseased plants, only become permanently infectious after three to four weeks (Orlovskis et al., 2017). In addition, since corn leafhoppers migrate from older to younger plants (Oliveira et al., 2013), later plantings
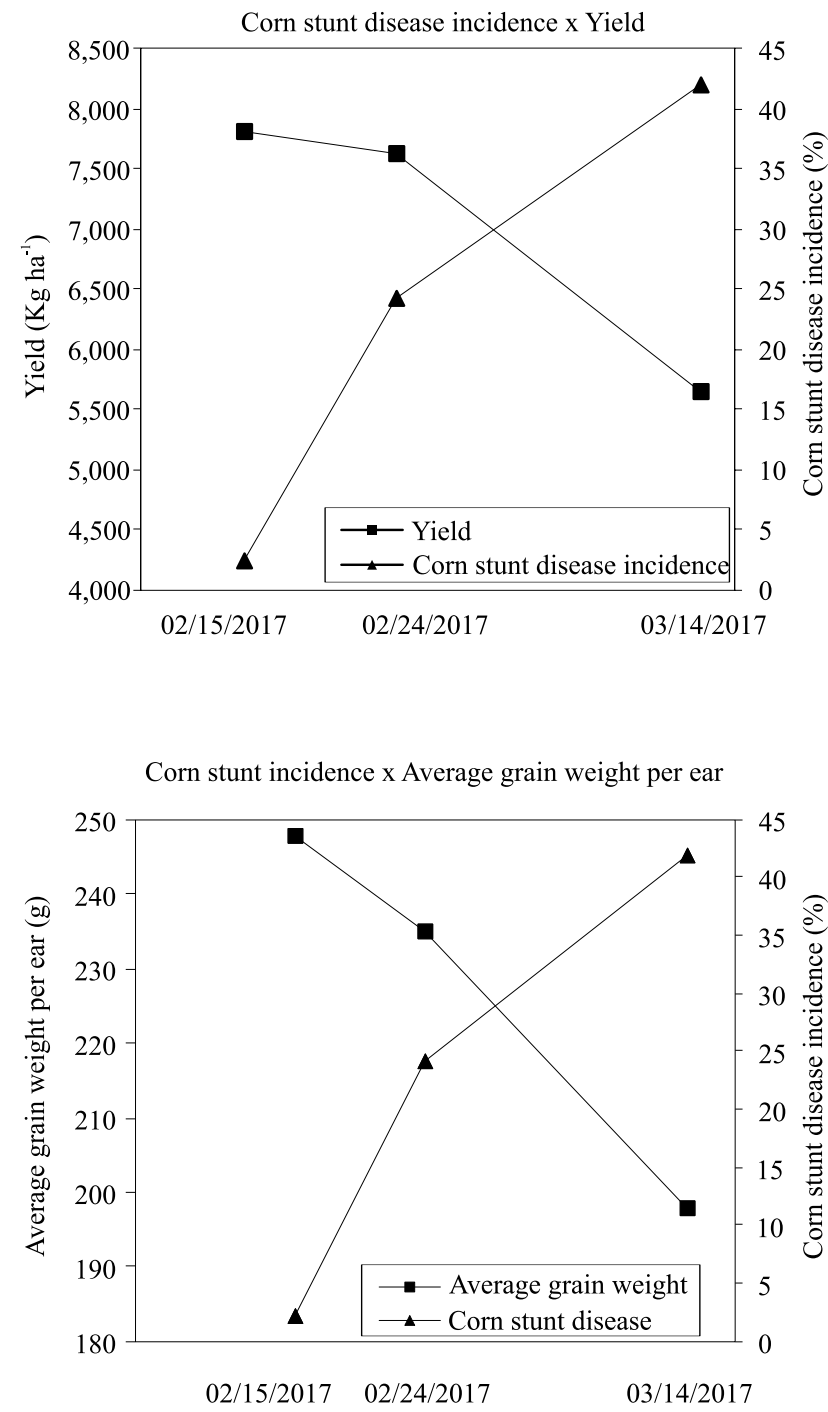

Figure 2. Corn stunt disease incidence and grain yield of corn (Zea mays) hybrids (A), and corn stunt disease incidence and average grain weight per ear (B) as a function of sowing season, in experiments conducted in the state of Tocantins, Brazil, in the 2017 off-season. also resulted in the exposure to an increased number of infectious insect vectors.

Seven hybrids (MG652 PW, Penta VIP, MG600 PW, NS90 PRO2, LG3040 VIP3, MG580 PW, and Defender VIP) maintained the same mean corn stunt disease incidence across the three study sites and did not differ from each other regarding the combined means of all sites (Table 2). Despite the delay in sowing, these hybrids were considered the most resistant, showing the lowest corn stunt disease incidences across the experimental sites. It should be highlighted that, although hybrid P3456 VYH is included in the group with the lowest disease incidence in the three sites, its average corn stunt disease incidence was $7.6 \%$, significantly higher than that of the hybrids considered resistant to the disease.

The corn stunt disease incidences in SYN5T78 VIP, LG6036 PRO, NS70, P2830 VYH, 2B512 PW, Supremo VIP, P30S31 VYH, and LG6033 PRO were equal to those of the resistant hybrids in the first two plantings, in Pedro Afonso and Porto Nacional. However, with the delay in sowing in Aparecida do Rio Negro, the disease incidences in these hybrids were higher than in the more resistant ones (Table 2). Therefore, delayed plantings should be avoided when using these hybrids.

In Pedro Afonso, the susceptibility standard hybrid, Fórmula VIP2, differed from the others in terms of disease incidence (Table 2). In Porto Nacional, the hybrids were classified into six groups (A-F), and 16 hybrids were among the most resistant, with mean incidences ranging from 2.5 to $8.5 \%$. The mean incidence of the disease was greater than $60 \%$ in the groups containing the most susceptible hybrids (E-F). Group F had only the susceptible hybrid, Fórmula VIP2, with a mean incidence of $79.5 \%$. In Aparecida do Rio Negro, the hybrids were classified into seven groups (A-G), and eight hybrids were among the most resistant, with mean disease incidences ranging from 2.5 to $13 \%$. In this site, $50 \%$ of the hybrids showed a mean corn stunt disease incidence greater than $50 \%$ (groups D-G), and Fórmula VIP2 differed from the other hybrids, with a $92.5 \%$ mean disease incidence.

Grain yield in Pedro Afonso ranged from 6,747.4 to $8,518.2 \mathrm{~kg} \mathrm{ha}^{-1}$, and the hybrids were divided into two grain yield groups (Table 3 ). A total of 16 hybrids were rated as high-yield, showing average yields of $8,068 \mathrm{~kg}$ $\mathrm{ha}^{-1}$, and 14 were low-yield, with average yields of 7,284 $\mathrm{kg} \mathrm{ha}^{-1}$. In Porto Nacional, grain yield ranged from 
5,783 to $9,111 \mathrm{~kg} \mathrm{ha}^{-1}$, and the hybrids were divided into three groups, including one with 15 high-yield hybrids, with average yields of $8,404.6 \mathrm{~kg} \mathrm{ha}^{-1}$, and another with four low-yield hybrids, with average yields of $6,448 \mathrm{~kg} \mathrm{ha}^{-1}$. The lowest grain yields were found in Aparecida do Rio Negro, ranging from 3,624 to 7,931 $\mathrm{kg} \mathrm{ha}^{-1}$, where the hybrids were divided into five grain yield groups. Only two hybrids were considered to be high-yield, MG580 PW and SYN5T78 VIP, showing an average yield of $7,570 \mathrm{~kg} \mathrm{ha}^{-1}$, whereas six hybrids were part of the low-yield group, with average yields of $4,310 \mathrm{~kg} \mathrm{ha}^{-1}$. The combined average of the three study sites allowed forming five grain yield groups, with 12 high-yield hybrids, showing average yields of 7,664 kg

Table 3. Yield and average grain weight per ear of corn (Zea mays) hybrids in experiments conducted in the municipalities of (PA - sowing 02/15/2017), Porto Nacional (PN - sowing 02/24/2017), and Aparecida do Rio Negro (ARN - sowing $03 / 14 / 2017)$, in the state of Tocantins, Brazil, in the off-season of $2017^{(1)}$.

\begin{tabular}{|c|c|c|c|c|c|c|c|c|}
\hline \multirow[t]{2}{*}{ Hybrids } & \multicolumn{3}{|c|}{ Yield $\left(\mathrm{kg} \mathrm{ha}^{-1}\right)$} & \multirow[t]{2}{*}{ Means } & \multicolumn{3}{|c|}{ Average grain weight per ear $(\mathrm{g})$} & \multirow[t]{2}{*}{ Means } \\
\hline & PA & PN & ARN & & PA & $\mathrm{PN}$ & $\mathrm{ARN}$ & \\
\hline MG580 PW & $8,133 \mathrm{Ab}$ & $9,111 \mathrm{Aa}$ & 7,931Ab & $8,392 \mathrm{~A}$ & $274 \mathrm{Aa}$ & $278 \mathrm{Aa}$ & $273 \mathrm{Aa}$ & $275 \mathrm{~A}$ \\
\hline SYN 5 T78 VIP & 8,316 Aa & 7,941Aa & $7,210 \mathrm{Aa}$ & $7,823 \mathrm{~A}$ & $283 \mathrm{Aa}$ & $272 \mathrm{Aa}$ & $258 \mathrm{Aa}$ & $272 \mathrm{~A}$ \\
\hline 2B810 PRO & $8,126 \mathrm{Aa}$ & $8,474 \mathrm{Aa}$ & $6,494 \mathrm{Bb}$ & $7,698 \mathrm{~A}$ & $252 \mathrm{Ba}$ & $259 \mathrm{Aa}$ & $214 \mathrm{Cb}$ & 244B \\
\hline MG600 PW & $8,518 \mathrm{Aa}$ & $8,408 \mathrm{Aa}$ & $6,166 \mathrm{Bb}$ & $7,697 \mathrm{~A}$ & 244Ba & $241 \mathrm{Ba}$ & $185 \mathrm{Cb}$ & $227 \mathrm{C}$ \\
\hline Supremo VIP & $7,648 \mathrm{Ba}$ & $8,441 \mathrm{Aa}$ & $6,670 \mathrm{Bb}$ & $7,586 \mathrm{~A}$ & $227 \mathrm{Ba}$ & $219 \mathrm{Ca}$ & $204 \mathrm{Ca}$ & $218 \mathrm{C}$ \\
\hline 2B512 PW & $8,329 \mathrm{Aa}$ & $8,056 \mathrm{Aa}$ & $6,365 \mathrm{Bb}$ & $7,583 \mathrm{~A}$ & $261 \mathrm{Aa}$ & $247 \mathrm{Ba}$ & $229 \mathrm{Ba}$ & 247B \\
\hline NS92 PRO2 & $8,024 \mathrm{Aa}$ & $8,073 \mathrm{Aa}$ & $6,630 \mathrm{Bb}$ & $7,575 \mathrm{~A}$ & $273 \mathrm{Aa}$ & $237 \mathrm{Bb}$ & $235 \mathrm{Bb}$ & 249B \\
\hline P30S31 VYH & $7,494 \mathrm{Bb}$ & $8,759 \mathrm{Aa}$ & $6,460 \mathrm{Bb}$ & $7,571 \mathrm{~A}$ & $250 \mathrm{Ba}$ & $276 \mathrm{Aa}$ & $223 \mathrm{Bb}$ & $252 \mathrm{~B}$ \\
\hline MG652 PW & $8,446 \mathrm{Aa}$ & $8,520 \mathrm{Aa}$ & $5,679 \mathrm{Bb}$ & $7,548 \mathrm{~A}$ & $271 \mathrm{Aa}$ & $257 \mathrm{Aa}$ & $199 \mathrm{Cb}$ & 246B \\
\hline Penta VIP & 7,952Aa & $8,867 \mathrm{Aa}$ & $5,800 \mathrm{Bb}$ & $7,540 \mathrm{~A}$ & $262 \mathrm{Aa}$ & $275 \mathrm{Aa}$ & $202 \mathrm{Cb}$ & $250 \mathrm{~B}$ \\
\hline SX7341 VIP3 & $7,561 \mathrm{Ba}$ & $8,555 \mathrm{Aa}$ & $6,418 \mathrm{Bb}$ & $7,511 \mathrm{~A}$ & $227 \mathrm{Ba}$ & $233 \mathrm{Ba}$ & $208 \mathrm{Ca}$ & $224 \mathrm{C}$ \\
\hline LG6036 PRO & $7,497 \mathrm{Bb}$ & 8,631Aa & $6,211 \mathrm{Bc}$ & $7,446 \mathrm{~A}$ & $243 \mathrm{Ba}$ & $260 \mathrm{Aa}$ & $199 \mathrm{Cb}$ & $237 \mathrm{~B}$ \\
\hline LG3040 VIP3 & 7,902Aa & 7,577Ba & $5,916 \mathrm{Bb}$ & $7,132 \mathrm{~B}$ & $270 \mathrm{Aa}$ & $239 \mathrm{Ba}$ & $187 \mathrm{Cb}$ & $236 \mathrm{~B}$ \\
\hline LG3055 PRO & $8,041 \mathrm{Aa}$ & $7,656 \mathrm{Ba}$ & $5,599 \mathrm{Bb}$ & $7,099 \mathrm{~B}$ & $304 \mathrm{Aa}$ & $260 \mathrm{Ab}$ & $198 \mathrm{Cc}$ & $259 \mathrm{~A}$ \\
\hline NS90 PRO2 & 7,746Aa & $8,028 \mathrm{Aa}$ & $5,447 \mathrm{Cb}$ & 7,074B & $237 \mathrm{Ba}$ & $238 \mathrm{Ba}$ & $199 \mathrm{Cb}$ & $227 \mathrm{C}$ \\
\hline NS70 & 7,896Aa & $7,554 \mathrm{Ba}$ & $5,715 \mathrm{Bb}$ & $7,055 \mathrm{~B}$ & $246 \mathrm{Ba}$ & $212 \mathrm{Ca}$ & $212 \mathrm{Ca}$ & $224 \mathrm{C}$ \\
\hline Defender VIP & $7,602 \mathrm{Ba}$ & $7,685 \mathrm{Ba}$ & $5,875 \mathrm{Bb}$ & $7,054 \mathrm{~B}$ & $209 \mathrm{Ca}$ & $215 \mathrm{Ca}$ & $194 \mathrm{Ca}$ & $207 \mathrm{D}$ \\
\hline DKB290 PRO3 & 7,864Aa & 7,938Aa & $5,139 \mathrm{Cb}$ & $6,980 \mathrm{~B}$ & $288 \mathrm{Aa}$ & $274 \mathrm{Aa}$ & $190 \mathrm{Cb}$ & $256 \mathrm{~A}$ \\
\hline DKB390 PRO3 & 7,795Aa & $7,465 \mathrm{Ba}$ & $5,291 \mathrm{Cb}$ & $6,850 \mathrm{C}$ & $227 \mathrm{Ba}$ & $212 \mathrm{Ca}$ & $194 \mathrm{Ca}$ & $213 \mathrm{C}$ \\
\hline Truck VIP & $6,949 \mathrm{Ba}$ & $7,438 \mathrm{Ba}$ & $6,143 \mathrm{Bb}$ & $6,843 \mathrm{C}$ & $206 \mathrm{Ca}$ & $198 \mathrm{Da}$ & $190 \mathrm{Ca}$ & 199D \\
\hline RIBER 9110 PRO & $8,237 \mathrm{Aa}$ & 7,743Ba & $4,349 \mathrm{Db}$ & $6,777 \mathrm{C}$ & $248 \mathrm{Ba}$ & $209 \mathrm{Cb}$ & 159Dc & $210 \mathrm{D}$ \\
\hline P30F35 & $7,269 \mathrm{Ba}$ & $6,581 \mathrm{Ca}$ & $6,283 \mathrm{Ba}$ & $6,711 \mathrm{C}$ & $198 \mathrm{Ca}$ & $177 \mathrm{Da}$ & $189 \mathrm{Ca}$ & $188 \mathrm{D}$ \\
\hline Fórmula VIP2 & $7,184 \mathrm{Bb}$ & $8,267 \mathrm{Aa}$ & $4,653 \mathrm{Dc}$ & $6,701 \mathrm{C}$ & $234 \mathrm{Ba}$ & $201 \mathrm{Cb}$ & $174 \mathrm{Db}$ & $206 \mathrm{D}$ \\
\hline P2830 VYH & $7,138 \mathrm{Ba}$ & $7,114 \mathrm{Ba}$ & $5,410 \mathrm{Cb}$ & $6,554 \mathrm{C}$ & $229 \mathrm{Ba}$ & $226 \mathrm{Ca}$ & $194 \mathrm{Ca}$ & $218 \mathrm{C}$ \\
\hline BM3063 PRO2 & $7,090 \mathrm{Ba}$ & $6,570 \mathrm{Ca}$ & $5,507 \mathrm{Cb}$ & $6,389 \mathrm{D}$ & $244 \mathrm{Ba}$ & $212 \mathrm{Cb}$ & $196 \mathrm{Cb}$ & $219 \mathrm{C}$ \\
\hline LG6033 PRO & 7,766Aa & $7,629 \mathrm{Ba}$ & $3,624 \mathrm{Db}$ & $6,339 \mathrm{D}$ & $287 \mathrm{Aa}$ & $271 \mathrm{Aa}$ & $135 \mathrm{Db}$ & $240 \mathrm{~B}$ \\
\hline 2B655 PW & $6,747 \mathrm{Ba}$ & $7,165 \mathrm{Ba}$ & $4,951 \mathrm{Cb}$ & $6,288 \mathrm{D}$ & $216 \mathrm{Ca}$ & $240 \mathrm{Ba}$ & $182 \mathrm{Cb}$ & $216 \mathrm{C}$ \\
\hline LG6304 PRO & 7,331Ba & $7,114 \mathrm{Ba}$ & $4,398 \mathrm{Db}$ & $6,281 \mathrm{D}$ & $243 \mathrm{Ba}$ & $225 \mathrm{Ca}$ & $173 \mathrm{Db}$ & $217 \mathrm{C}$ \\
\hline DKB310 PRO3 & $6,886 \mathrm{Ba}$ & $6,857 \mathrm{Ca}$ & $4,643 \mathrm{Db}$ & $6,129 \mathrm{D}$ & $235 \mathrm{Ba}$ & $209 \mathrm{Cb}$ & $188 \mathrm{Cb}$ & $213 \mathrm{C}$ \\
\hline P3456 VYH & $7,580 \mathrm{Ba}$ & $5,783 \mathrm{Cb}$ & $4,193 \mathrm{Dc}$ & $5,852 \mathrm{D}$ & $260 \mathrm{Aa}$ & $178 \mathrm{Db}$ & $158 \mathrm{Db}$ & $202 \mathrm{D}$ \\
\hline Means & $7,702 \mathrm{a}$ & $7,799 a$ & $5,705 \mathrm{~b}$ & 7,069 & $248 \mathrm{a}$ & $235 b$ & $198 \mathrm{c}$ & 229 \\
\hline
\end{tabular}

${ }^{(1)}$ Means followed by equal letters, uppercase in the columns and lowercase in the rows, do not differ by the Scott-Knott test, at 5\% probability. 
$\mathrm{ha}^{-1}$, and six low-yield hybrids, with average yields of $6,212.9 \mathrm{~kg} \mathrm{ha}^{-1}$.

Although grain yield decreased with increased disease incidence due to the delay in sowing (Figure 2), Pearson's coefficient analysis showed an inverse, proportional, and median correlation of -0.5 between corn stunt disease incidence and grain yield. Therefore, the observed decrease in productivity cannot be explained exclusively by the increase in stunt disease incidence, because, in the second planting in the state of Tocantins, grain yield has been shown to gradually decrease in later sowing seasons because of increased water restriction in the final phase of the crop cycle (Costa et al., 2017).

The increase in corn stunt disease incidence in later plantings may account for most of the decrease in grain yield in the present study. In the first planting, in Pedro Afonso, with the lowest disease incidence, low-yield hybrids produced $9.7 \%$ fewer kernels than the high-yield ones. In contrast, in the last planting, in Aparecida do Rio Negro, with the highest corn stunt disease incidence and where resistance to disease was the most important, this difference increased to $43 \%$.

Mollicutes interfere with corn plant growth and development, reduce nutrient uptake, and affect photoassimilate translocation for grain filling (Magalhães et al., 2005), stimulating the proliferation of unproductive ears (Oliveira et al., 2008; Teixeira et al., 2013; Orlovskis et al., 2017) and decreasing plant resistance to water stress (Magalhães et al., 2001). This explains the greater difference in grain yield between resistant and susceptible hybrids in the later planting, when stunt disease incidence was the highest.

Corn stunt disease incidence increased ten-fold between the first planting in Pedro Afonso and the second one in Porto Nacional (Table 2), although the average grain yield of these sites remained unchanged (Table 3). The difference in sowing date between these two sites was of only nine days, meaning infectious corn leafhoppers migrated to the second planting when the corn crop was at an advanced stage of development, differently from what happen in the third planting, approximately a month after the first, when infection occurred at the beginning of the crop cycle, with a greater frequency of pathogen transmission. According to Toffanelli \& Bedendo (2002), earlier Mollicute infections lead to worsened disease symptoms and further impair corn plant development.
Regarding AGWE, 36.6\% of the hybrids did not differ among the three study sites (Table 3). MG580 PW and SYN5T78 VIP had the highest values for this variable in all sites, whereas DKB290 PRO3, LG3055 PRO, LG6033 PRO, MG580 PW, MG652 PW, Penta VIP, and SYN5T78 VIP had the highest values in Pedro Afonso and Porto Nacional.

Pearson's correlation coefficient also showed an inverse, proportional, and median correlation of -0.5 between stunt disease incidence and AGWE. This variable gradually decreased in later crops with increased disease incidence (Figure 2) and with decreased rainfall (Figure 1) during the crop cycle (Costa et al., 2017). In the first planting in Pedro Afonso, the AGWE of the hybrids was $248 \mathrm{~g}$, decreasing by $5.2 \%$ in the second plating in Porto Nacional, and by $20 \%$ in the third planting in Aparecida do Rio Negro, both showing average yields of $198 \mathrm{~g}$.

The inversely proportional relationship between corn stunt disease incidence and AGWE (Figure 2) indicates how the disease affected grain yield. The shortened internodes caused by Mollicutes reduce the photoassimilate reserves used by the plant during the grain-filling period, leading to the formation of lighter grains (Magalhães et al., 1998). The difference in AGWE between high- and low-yield hybrids in the first planting, which had higher and lower corn stunt disease incidence, respectively, was $24 \%$, whereas, in the last planting in Aparecida do Rio Negro, where a higher disease incidence was observed, this difference was $40 \%$.

In the present study, a high genetic variability in resistance to stunt disease was verified among hybrids. In addition, the experiments conducted in different sowing seasons and sites highlighted the importance of the assessed factors in the reaction of the hybrids to the disease.

Some hybrids had low disease incidence in all three sites and were, therefore, considered the most resistant (Table 2). Others were resistant in the first two plantings, but were susceptible in the last one. Therefore, experiments aiming to evaluate commercial hybrids or corn lines for resistance to stunt disease in improvement programs should be performed in late sowing seasons to subject plants to a high population of infectious vectors and, consequently, a high disease incidence. 


\section{Conclusions}

1. Corn (Zea mays) hybrids are highly variable in terms of resistance to corn stunt disease.

2. The MG652 PW, Penta VIP, MG600 PW, NS90 PRO2, LG3040 VIP3, MG580 PW, and Defender VIP hybrids are the most resistant to corn stunt disease.

3. Corn stunt disease incidence increases in later sowing seasons, which decreases grain yield.

4. The MG580 PW, SYN 5T78 VIP, 2B810 PRO, MG600 PW, Supremo VIP, 2B512 PW, NS92 PRO2, P30S31 VYH, MG652 PW, Penta VIP, SX5371 VIP3, and LG6036 PRO hybrids are the most productive.

\section{Acknowledgments}

To Embrapa Aquicultura e Pesca and to Embrapa Milho e Sorgo, for financial support.

\section{References}

COSTA, R.V. da; SIMON, J.; SILVA, D.D. da; COTA, L.V.; ALMEIDA, R.E.M. de; CAMPOS, L.J.M. Cultivares de milho afetadas pela época de semeadura na safrinha em Tocantins. Revista Brasileira de Milho e Sorgo, v.16, p.469-480, 2017. DOI: https://doi.org/10.18512/1980-6477/rbms.v16n3p469-480.

MAGAlHÃES, P.C.; DURÃES, F.O.M; OLIVEIRA, A.C. de. Efeitos do quebramento do colmo no rendimento de grãos de milho. Ciência e Agrotecnologia, v.22, p.279-289, 1998.

MAGALHÃES, P.C.; OLIVEIRA, E. de; GOMIDE, R.L.; VASCONCELOS, C.A.; SOUZA, I.R.P. Aspectos fisiológicos de plantas de milho infectadas por molicutes sob diferentes níveis de água no solo. Revista Brasileira de Fisiologia Vegetal, v.13, p.293-301, 2001. DOI: https://doi.org/10.1590/S010331312001000300005 .

MAGALHÃES, P.C.; OLIVEIRA， E. de; SOUZA， I.R.P.; DURÃES, F.O.M.; OLIVEIRA, C.M.; OLIVEIRA, A.C. de. Alterações nos níveis relativos de açúcares solúveis totais e de proteínas em plantas de milho infectadas com molicutes. Revista Brasileira de Milho e Sorgo, v.4, p.335-343, 2005.

MARQUARDT, P.T.; TERRY, R.M.; JOHNSON, W.G. The impact of volunteer corn on crop yields and insect resistance management strategies. Agronomy, v.3, p.488-496, 2013. DOI: https://doi.org/10.3390/agronomy3020488.

MORO, J.R.; SILVEIRA, F.T.; CARGNELUTTI FILHO, A. Dissimilaridade genética em sessenta e quatro linhagens de milho avaliadas para resistência ao complexo enfezamento. Revista de Biologia e Ciências da Terra, v.7, p.153-160, 2007.

NAULT, L.R. Maize bushy stunt and corn stunt: a comparison of disease symptoms, pathogen host ranges, and vectors. Phytopathology, v.70, p.659-662, 1980. DOI: https://doi.org/10.1094/Phyto-70-659.
OLIVEIRA, C.M. de; LOPES, J.R.S.; CAMARGO, L.E.A.; FUNGARO, M.H.P.; NAULT, L.R. Genetic diversity in populations of Dalbulus maidis (DeLong and Wolcott) (Hemiptera: Cicadellidae) from distant localities in Brazil assessed by RAPDPCR markers. Molecular Ecology and Evolution, v.36, p.204212, 2007. DOI: https://doi.org/10.1603/0046-225x(2007)36[204:g dipod]2.0.co;2.

OLIVEIRA, C.M. de; OLIVEIRA, E. de; CANUTO, M.; CRUZ, I. Eficiência de inseticidas em tratamento de sementes de milho no controle da cigarrinha Dalbulus maidis (Hemiptera: Cicadellidae) em viveiro telado. Ciência Rural, v.38, p.231-235, 2008. DOI: https://doi.org/10.1590/S0103-84782008000100037.

OLIVEIRA, C.M. de; SABATO, E. de O. Controle químico da cigarrinha Dalbulus maidis efeito na incidência dos enfezamentos do milho. In: OLIVEIRA, C.M. de; SABATO, E. de O. (Ed.). Doenças em milho: insetos-vetores, molicutes e vírus. Brasília: Embrapa, 2017. p.113-120.

OLIVEIRA， C.M.; LOPES， J.R.S.; NAULT, L.R. Survival strategies of Dalbulus maidis during maize off-season in Brazil. Entomologia Experimentalis et Applicata, v.147, p.141-153, 2013. DOI: https://doi.org/10.1111/eea.12059.

OLIVEIRA, E. de; RESENDE, R. de O.; GIMÉNEZ PECCI, M. de la P.; LAGUNA, I.G.; HERRERA, P.; CRUZ, I. Incidência de viroses e enfezamentos e estimativa de perdas causadas por molicutes em milho no Paraná. Pesquisa Agropecuária Brasileira, v.38, p.19-25, 2003. DOI: https://doi.org/10.1590/ S0100-204X2003000100003.

ORLOVSKIS, Z.; CANALE, M.C.; HARYONO, M.; LOPES, J.R.S.; KUO, C.-H.; HOGENHOUT, S.A. A few sequence polymorphisms among isolates of Maize bushy stunt phytoplasma associate with organ proliferation symptoms in infected maize plants. Annals of Botany, v.119, p.869-884, 2017. DOI: https://doi. org/10.1093/aob/mcw213.

SANTOS, H.G. dos; JACOMINE, P.K.T.; ANJOS, L.H.C. dos; OLIVEIRA, V.A. de; LUMBRERAS, J.F.; COELHO, M.R.; ALMEIDA, J.A. de; CUNHA, T.J.F.; OLIVEIRA, J.B. de. Sistema brasileiro de classificação de solos. 3.ed. rev. e ampl. Brasília: Embrapa, 2013. 353p.

SILVA, D.D. da; AGUIAR, F.M.; COTA, L.V.; COSTA, R.V. da; MENDES, S.M. Molicutes em milho: a diversificação de sistemas de produção pode ser a solução? In: MEDEIROS, F.H.V.; PEDROSO, L.A.; GUIMARÃES, M. de R.F.; SILVA, B.A.A. de S. e; ALMEIDA, L.G.F. de; SILVA, F. de J.; SILVA, R.L.M. da; FERREIRA, L.C.; PEREIRA, A.K.M.; COUTO, T.B.R.; GOMES, V.A.; MEDEIROS, R.M.; VEIGA, C.M. de O.; SILVA, M. de F.; FIGUEIREDO, Y.F.; GATTI, G.V.N.; NICOLLI, C.P. (Ed.). Novos sistemas de produção. Lavras: Universidade Federal de Lavras, 2017. p.32-52.

SILVEIRA, F.T.; MORO, J.R.; SILVA, H.P. da; OLIVEIRA, J.A. de; PERECIN, D. Herança da resistência ao enfezamento em milho. Pesquisa Agropecuária Brasileira, v.43, p.1717-1723, 2008. DOI: https://doi.org/10.1590/S0100-204X2008001200011.

TEIXEIRA, F.F.; COSTA, F.M.; SÁBATO, E. de O.; LEITE, C.E.P.; MEIRELLES, W.F.; GUIMARÃES, C.T.; BELICUAS, S.N.J. Pré-melhoramento de milho quanto à resistência a 
enfezamentos. Pesquisa Agropecuária Brasileira, v.48, p.51-58, 2013. DOI: https://doi.org/10.1590/S0100-204X2013000100007.

TOFFANELLI, C.M.; BEDENDO, I.P. Efeito da população infetiva de Dalbulus maidis na produção de grãos e no desenvolvimento de sintomas do enfezamento vermelho do milho. Fitopatologia Brasileira, v.27, p.82-86, 2002. DOI: https://doi.org/10.1590/ S0100-41582002000100013.
WHITCOMB, R.F.; CHEN, T.A.; WILLIAMSON, D.L.; LIAO, C.; TUlly, J.G.; BOVÉ, J.M.; MOUCHES, C.; ROSE, D.L.; COAN, M.E.; CLARK, T.B. Spiroplasma kunkelii sp. nov.: characterization of the etiological agent of corn stunt disease. International Journal of Systematic Bacteriology, v.36, p.170-178, 1986. DOI: https://doi.org/ 10.1099/00207713-36-2170 . 